\title{
Cold atmospheric plasma as a potential tool for multiple myeloma treatment
}

\author{
Dehui $X u^{1,2, *}$, Yujing $X u^{1, *}$, Qingjie Cui ${ }^{2}$, Dingxin Liu ${ }^{1}$, Zhijie Liü ${ }^{1}$, Xiaohua Wang ${ }^{1}$, \\ Yanjie Yang ${ }^{3}$, Miaojuan Feng ${ }^{4}$, Rong Liang ${ }^{4}$, Hailan Chen ${ }^{5}$, Kai $\mathbf{Y e}^{6,7}$ and Michael G. \\ Kong ${ }^{1,5,8}$ \\ ${ }^{1}$ State Key Laboratory of Electrical Insulation and Power Equipment, Center for Plasma Biomedicine, Xi'an Jiaotong University, \\ Xi'an, Shaanxi, 710049, P.R. China \\ ${ }^{2}$ The School of Life Science and Technology, Xi'an Jiaotong University, Xi'an, Shaanxi, 710049, P.R. China \\ ${ }^{3}$ Department of Cardiovascular Medicine, First Affiliated Hospital of the Medical School, Xi'an Jiaotong University, Xi'an, \\ Shaanxi, 710061, P.R. China \\ ${ }^{4}$ Department of Hematology, Xijing Hospital, Fourth Military Medical University, Xi'an, Shaanxi, 710032, P.R. China \\ ${ }^{5}$ Frank Reidy Center for Bioelectrics, Old Dominion University, Norfolk, VA, 23508, USA \\ ${ }^{6}$ School of Electronic and Information Engineering, Xi'an Jiaotong University, Xi'an, Shaanxi, 710049, P.R. China \\ ${ }^{7}$ First Affiliated Hospital of the Medical School, Xi'an Jiaotong University, Xi'an, Shaanxi, 710061, P.R. China \\ ${ }^{8}$ Department of Electrical and Computer Engineering, Old Dominion University, Norfolk, VA, 23529, USA \\ *These authors have contributed equally to this work \\ Correspondence to: Michael G. Kong, email: mkong@odu.edu \\ Kai Ye, email: ed_kaiye@mail.xjtu.edu.cn
}

Keywords: multiple myeloma; cold atmospheric plasma; reactive oxygen species; CD95; selective inactivation

Received: November 09, $2017 \quad$ Accepted: January 30, $2018 \quad$ Published: April 06, 2018

Copyright: $\mathrm{Xu}$ et al. This is an open-access article distributed under the terms of the Creative Commons Attribution License 3.0 (CC BY 3.0), which permits unrestricted use, distribution, and reproduction in any medium, provided the original author and source are credited.

\section{ABSTRACT}

Multiple myeloma (MM) is a fatal and incurable hematological malignancy thus new therapy need to be developed. Cold atmospheric plasma, a new technology that could generate various active species, could efficiently induce various tumor cells apoptosis. More details about the interaction of plasma and tumor cells need to be addressed before the application of gas plasma in clinical cancer treatment. In this study, we demonstrate that $\mathrm{He}+\mathrm{O}_{2}$ plasma could efficiently induce myeloma cell apoptosis through the activation of CD95 and downstream caspase cascades. Extracellular and intracellular reactive oxygen species (ROS) accumulation is essential for CD95-mediated cell apoptosis in response to plasma treatment. Furthermore, p53 is shown to be a key transcription factor in activating CD95 and caspase cascades. More importantly, we demonstrate that CD95 expression is higher in tumor cells than in normal cells in both MM cell lines and MM clinical samples, which suggests that CD95 could be a favorable target for plasma treatment as it could selectively inactivate myeloma tumor cells. Our results illustrate the molecular details of plasma induced myeloma cell apoptosis and it shows that gas plasma could be a potential tool for myeloma therapy in the future.

\section{INTRODUCTION}

Multiple myeloma (MM), the second most common hematological malignancy characterized by the accumulation of malignant plasma cells (PCs) in the bone marrow $(\mathrm{BM})$ of patients, results in the production of monoclonal immunoglobulin (also known as 'M-protein') and substantial immune-suppression and end-organ 
damage such as anemia, thrombocytopenia, renal failure, and bone disease [1]. In nonrandomized MM clinical trials, high-dose chemotherapy is recommended with an autologous transplant, which results in the highest response rates [2, 3]. However, despite great progress in novel anti-myeloma drugs and therapies, most of the patients relapse and become resistant to chemotherapy [4], which makes MM a fatal and incurable hematological malignancy. Regulation of redox homeostasis is one strategy for cancer treatment, as long-term ROS simulation plays an important role in cancer development through oxidative DNA damage and gene mutations [5, 6]. Radiation and several chemotherapy drugs can produce extracellular and intracellular ROS, thus disrupting redox homeostasis, which can induce tumor cell apoptosis $[7,8]$. Cell apoptosis are mainly conducted by three pathways: mitochondrial pathway, extrinsic pathway such as death receptors (DR) and tumor necrosis factor receptor (TNF), endoplasmic reticulum (ER) stress pathway $[9,10]$. In this study, we investigated whether CD95, a key death receptor that is pivotal for the induction of tumor cell apoptosis and is a major target in cancer therapy $[11,12]$, is involved in plasma induced cell apoptosis. It was reported that CD95 is widely expressed in patient myeloma cells and myeloma cell lines $[13,14]$. Anti-CD95 antibodies could directly target CD95; however, only some samples exhibited cell apoptosis [15]. ROS accumulation could also regulate CD95, thus activating CD95-mediated tumor cell apoptosis $[16,17]$. In addition to radio- and chemotherapies, a new technology called cold atmospheric plasma (CAP) could provide controllable exogenous reactive oxygen and nitrogen species $[18,19]$. Plasmas are ionized gases, comprising a complex mixture of charged particles, neutral gas molecules, UV radiation, electric fields and reactive species [20]. Owing to technological advancements, it is now possible to generate plasmas at atmospheric pressure and room temperature (e.g., CAP), which enables the application of plasma in a range of biomedical processes such as wound healing, disinfection and cancer treatment $[21,22]$. Most plasma devices could be divided into two types: plasma jet and Dielectric Barrier Discharger (DBD) [23-25]. CAP is a favorable source of reactive oxygen and nitrogen species, and it has been found to be efficient for killing tumor cells in various types of cancer, including lung cancer, leukemia, intestinal cancer, melanoma, cervical cancer, glioma, pancreatic cancer et al. [26-29]. The induction of apoptosis in cancer cells has been widely reported, and the mechanism of plasma-induced apoptosis is increasingly being understood [30-32]. It is reported that plasma could affect various cancer cell signaling such as AGP-ROS, MAPK, p53 and $\mathrm{PI} 3 \mathrm{~K} / \mathrm{AKT}$ pathway and induced cell apoptosis [33]. In this study, we first demonstrated that CD95 was involved in plasma-induced cancer cell apoptosis. Up-regulation of CD95 was positively correlated with the accumulation of extracellular and intracellular ROS. By chromatin immune-precipitation (ChIP) assay, we demonstrated that p53, which was up-regulated by plasma treatment, could bind to the CD95 promoter region and increase CD95 expression, resulting in the activation of caspase signaling and induction of apoptosis. Furthermore, because of the differential expression of CD95 in normal and myeloma cells, plasma could selectively inactivate tumor cells in myeloma cell lines and patient samples. Our results provide a new strategy for potential myeloma therapy by targeting CD95 with cold atmospheric plasma.

\section{RESULTS}

\section{Characteristics of plasma generation}

He plasma was generated at the voltage of $10 \mathrm{kHz} / 8$ $\mathrm{kV}$ with a $\mathrm{He}$ gas flow of $2 \mathrm{SLM}$. Additional $\mathrm{O}_{2}$ was mixed in to produce more ROS. (Figure $1 \mathrm{~A}$ and $1 \mathrm{~B}$ ) show the structure of the plasma jet and photographs of $\mathrm{He} / \mathrm{He}+\mathrm{O}_{2}$ plasmas. Additional $\mathrm{O}_{2}$ decreased the intensity of the plasma and changed the plasma plume from purple to gray. (Figure 1C) shows the corresponding applied voltage and current during $\mathrm{He}+\mathrm{O}_{2}$ plasma generation. To investigate the different reactive species in the plasma, we used a spectrometer to measure the emission spectra. As shown in (Figure 1D), there were several spectral lines (e.g., OH (A) 309 nm, N (C) $_{2} 37$ $\mathrm{nm}, \mathrm{N}_{2}^{+}$(B) $391 \mathrm{~nm}, \mathrm{He}\left(3 \mathrm{~s}^{3} \mathrm{~S}^{1}\right) 706 \mathrm{~nm}$ and $\mathrm{O}\left(3 \mathrm{p}^{5} \mathrm{P}\right) 777$ $\mathrm{nm})$ present in the plasma and they were marked according to the literature $[34,35]$. The intensity of the plasma components gradually decreased when the percentage of mixed $\mathrm{O}_{2}$ was increased from $0 \%$ to $1 \%$ (Figure $1 \mathrm{E}$ ).

\section{Decrease in cell viability and induction of apoptosis after plasma treatment for different durations}

We treated LP-1 MM cells with CAP and investigated the biological effects of plasma. CellTiterGlo assay showed that the cell viability $24 \mathrm{~h}$ and $48 \mathrm{~h}$ after He plasma treatment gradually decreased in a timedependent manner (Figure 2A). Next, we added $\mathrm{O}_{2}$ to $\mathrm{He}$ to generate $\mathrm{He}+\mathrm{O}_{2}$ plasma, which could produce more ROS. We added $\mathrm{O}_{2}$ at $0.2 \%, 0.5 \%$ and $1 \%$ of the total mixture. Because $\mathrm{O}_{2}$ is a electronegative gas, a mixture with greater than $1 \%$ of $\mathrm{O}_{2}$ will eliminate plasma generation. (Figure 2B) shows the cell viability $24 \mathrm{~h}$ after the application of the various compositions of $\mathrm{He}+\mathrm{O}_{2}$ plasma. The addition of $0.2 \% \mathrm{O}_{2}$ didn't promote LP-1 cell death compared to $\mathrm{He}+0 \% \mathrm{O}_{2}$, and the cell viability of $\mathrm{He}+0.5 \% \mathrm{O}_{2}$ treatment was sharply decreased and much lower than other groups when the treatment time was over $30 \mathrm{~s}$. Referring to the intensity and stability of the plasma (Figure 1E), we chose the $\mathrm{He}+0.5 \% \mathrm{O}_{2}$ plasma for use in our following experiments. (Figure 2C) shows apoptosis in the cells detected by flow cytometry $24 \mathrm{~h}$ after $\mathrm{He}+0.5 \% \mathrm{O}_{2}$ treatment. 

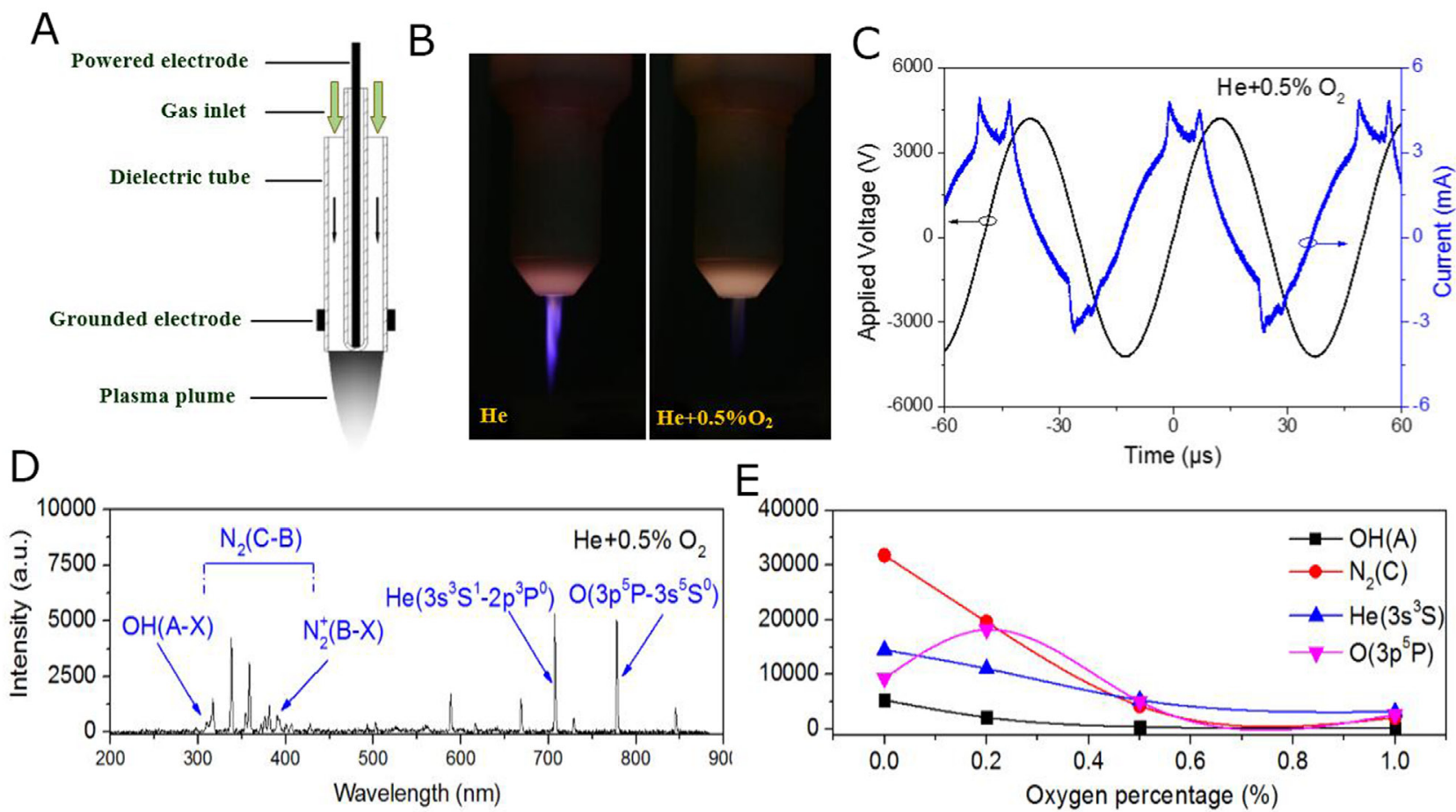

Figure 1: Characteristics of the plasma generation system. (A) Schematic representation of the plasma jet. (B) Photographs of $\mathrm{He}$ plasma and $\mathrm{He}+\mathrm{O}_{2}$ plasmas. (C) Monitoring of the applied voltage and current during $\mathrm{He}+\mathrm{O}$, plasma generation. (D) Emission spectra of different $\mathrm{He}+\mathrm{O}_{2}$ plasmas detected by the spectrometer. Some unique spectral lines $\left(\mathrm{OH}, \mathrm{N}_{2}, \mathrm{He}\right.$ and $\left.\mathrm{O}\right)$ in the $\mathrm{He}+0.5 \%$ O plasmas are marked. (E) The intensity of several characteristic spectral lines are shown with varying $\mathrm{O}_{2}$ percentage in the working gas.
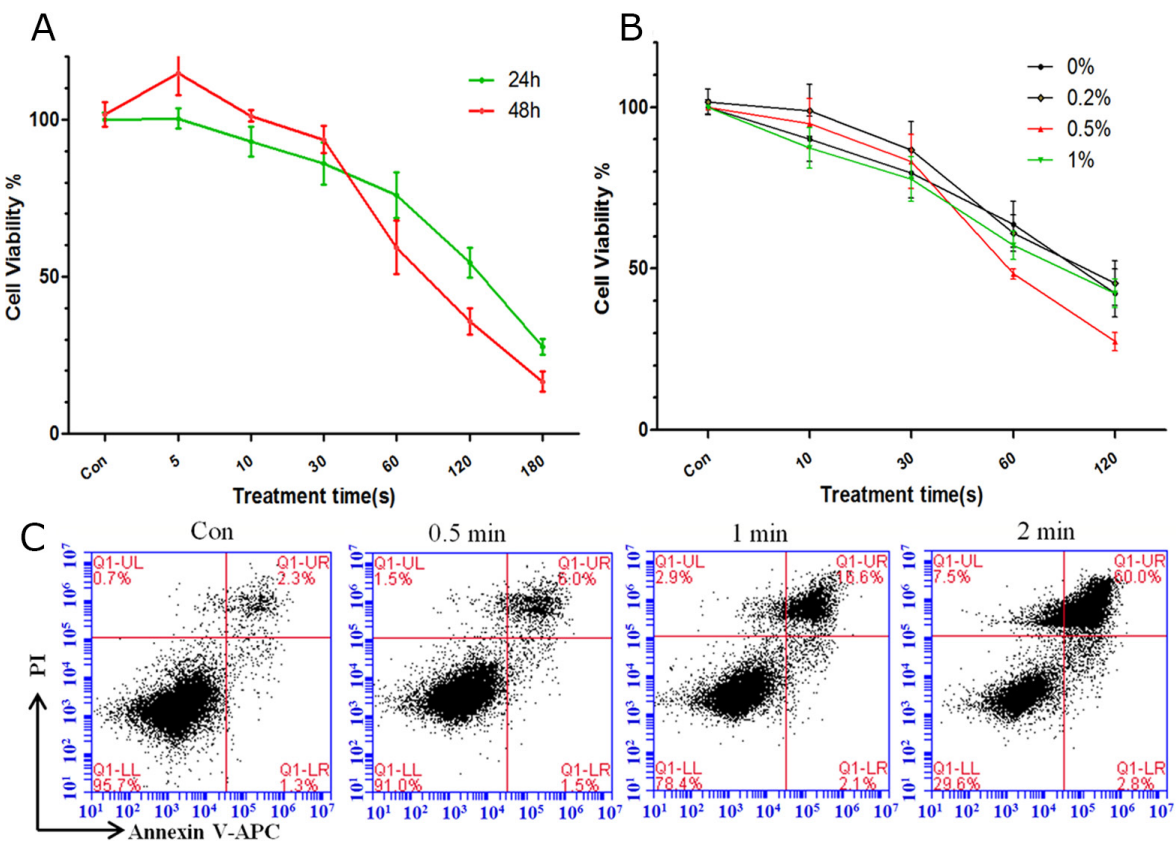

Figure 2: Cell viability and apoptosis after plasma treatment for different durations. (A) Analysis of cell viability $24 \mathrm{~h}$ and $48 \mathrm{~h}$ after He plasma treatment for different durations. (B) Analysis of cell viability $24 \mathrm{~h}$ after $\mathrm{He}+\mathrm{O}_{2}$ plasma for different durations. (C) Cell apoptosis analyzed by flow cytometry after $\mathrm{He}+0.5 \% \mathrm{O}_{2}$ plasma treatment for 0.5 , 1 , and 2 min. 


\section{Changes in mitochondrial membrane potential (MMP), lysosomal leakage and activation of the caspase cascades after plasma treatment}

Changes in MMP (JC-1 staining) are known indicators of early apoptosis [11]. By fluorescence microscopy, we showed that the red fluorescence (JC-1 aggregates) declined after $\mathrm{He}+\mathrm{O}_{2}$ plasma treatment (Figure $3 \mathrm{~A}$ ), which was further confirmed by flow cytometry (Figure 3B). Lysosomal leakage assay (stained by lucifer yellow dye) showed that plasma treatment resulted in the release of the dye from lysosomes into the cytoplasm, generating diffuse green staining instead of the punctate pattern seen in the control (Figure 3C). Since the activation of caspase cascades plays a central role in apoptosis, we investigated enzyme activity of caspase $3 / 8 / 9$ at $3 \mathrm{~h}$ and $6 \mathrm{~h}$ after $\mathrm{He}+\mathrm{O}_{2}$ plasma treatment. The results showed that the enzyme activity of caspase $3 / 8$ was increased by plasma treatment, while that of caspase 9 increased slightly only at $6 \mathrm{~h}$ after treatment (Figure 3D). Western blotting results showed that caspase $3 / 8 / 9(32 \mathrm{kD}, 31 \mathrm{kD}$ and $18 \mathrm{kD}$, respectively) were all increased after plasma treatment (Supplementary Figure 1). Cleaved caspase8 (43 kD and $41 \mathrm{kD}$ ) exhibited a significant increase, while that of caspase $8(55 \mathrm{kD})$ remained the same after plasma treatment. The level of caspase $9(47 \mathrm{kD})$ was slightly increased after plasma treatment. These results indicated that caspase 3 and caspase 8 were the main factors activating the apoptotic process.

\section{Analysis of apoptosis-related protein array after $\mathrm{He}+\mathrm{O}_{2}$ plasma treatment}

To elucidate the molecular mechanism of plasmainduced cell apoptosis, a human apoptosis protein array containing 35 apoptosis-related proteins was used 24 $\mathrm{h}$ after $\mathrm{He}+\mathrm{O}_{2}$ treatment for $60 \mathrm{~s}$. As shown in (Figure 4A), the level of cytochrome $\mathrm{C}$ was decreased, while that of CD95 and phospho-p53 was significantly increased by plasma treatment. As CD95 is a key cell
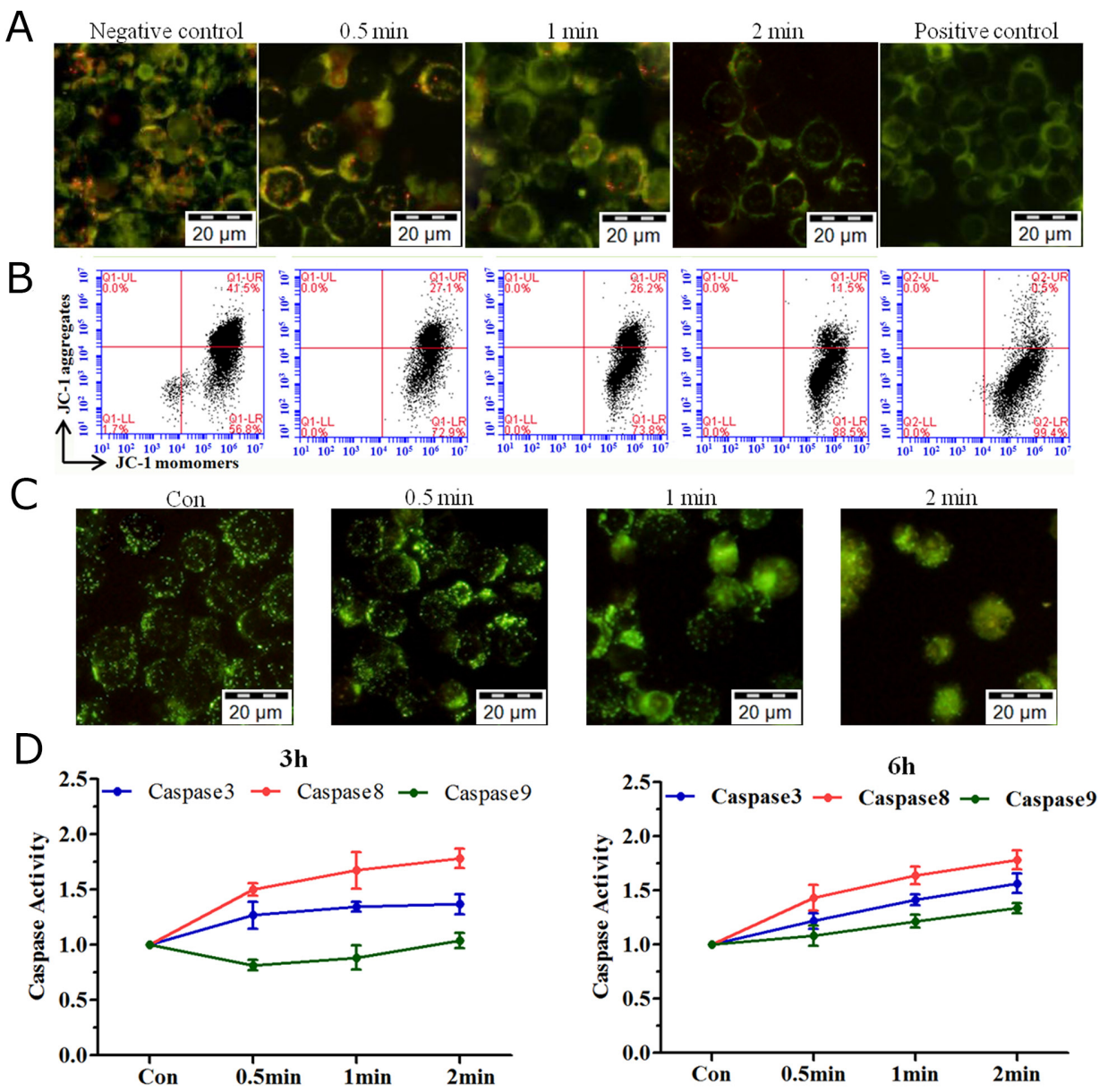

Figure 3: MMP, lysosomal leakage and caspase activation induced by plasma treatment. (A, B) LP-1 cells stained with a reporter dye, JC-1, for mitochondrial condition are detected by (A) fluorescence microscopy and (B) flow cytometry. (C) Analysis of lysosomal leakage in LP-1 cells indicated by fluorescence staining with Lucifer yellow after plasma treatment for 0.5, 1 and 2 min. (D) The activity of caspase 3/8/9 was measured with a Caspase Colorimetric Assay Kit 3 h and 6 h after plasma treatment. 
death receptor (DR), we confirmed CD95 expression by flow cytometry after plasma treatment. The results showed that CD95 was up-regulated in a timedependent manner by $\mathrm{He}+\mathrm{O}_{2}$ treatment (Figure 4B). These results indicated that CD95 might be involved in plasma-induced cell apoptosis.

\section{Down-regulation of CD95 reduced plasma- induced cell apoptosis}

We used CD95-targeting short interfering RNAs (siRNA) to down-regulate CD95 expression and assessed the effect of plasma on cell apoptosis. $48 \mathrm{~h}$ after siRNA transfection, we detected CD95 expression by flow cytometry, real-time PCR and western blotting. As shown in (Figure 5A), the percentage of CD95 ${ }^{+}$cells was decreased after siRNA transfection. CD95 expression at mRNA and protein levels was also decreased compared to that of the control. The percentage of $\mathrm{CD}^{+} 5^{+}$cells (Figure 5B) and corresponding cell viability (Figure 5C) after CD95 knockdown and plasma treatment was investigated. CD95 expression and cell viability was negatively correlated. Down-regulating CD95 could reduce cell viability reduction caused by plasma treatment. By Annexin-V/PI staining, we further confirmed that compared to the control, down-regulation of CD95 could reduce cell apoptosis induced by $\mathrm{He}+\mathrm{O}_{2}$ plasma treatment for $1 \mathrm{~min}$ (Figure 5D). These results indicated that CD95 is involved in $\mathrm{He}+\mathrm{O}_{2}$ plasmainduced cell apoptosis.

\section{ROS accumulation is essential for CD95- mediated cell apoptosis by plasma treatment}

As ROS produced by plasma are considered to play an important role in biological processes, we investigated extracellular and intracellular levels of ROS after $\mathrm{He}+\mathrm{O}_{2}$ plasma treatment. Extracellular ROS level was significantly increased immediately after plasma treatment, while at $24 \mathrm{~h}$ and $48 \mathrm{~h}$ after treatment, it was only slightly higher than the level before treatment (Figure 6A). NAC, which is a general ROS scavenger, could efficiently eliminate extracellular ROS accumulation at a final concentration of $5 \mathrm{mM}$ or $10 \mathrm{mM}$. Meanwhile, NAC alone $(5 \mathrm{mM}$ or 10 $\mathrm{mM}$ ) had no cell toxicity on LP-1 cells as no reduction of cell viability was detected after adding NAC for $24 \mathrm{~h}$ and 48 h. Intracellular ROS was detected by flow cytometry, and the results showed that there was no difference immediately after plasma treatment, or in a short time ( $3 \mathrm{~h}$ and $6 \mathrm{~h}$ ) after plasma treatment (data not shown), but the level was significantly increased $24 \mathrm{~h}$ after plasma treatment (Figure 6B). NAC not only eliminated extracellular ROS but also blocked the intracellular ROS accumulation despite the various durations of plasma treatment. Cell viability assay revealed that preventing ROS accumulation by NAC could reduce plasma-induced cell apoptosis measured at $0 \mathrm{~h}$, $24 \mathrm{~h}$ and $48 \mathrm{~h}$ (Figure 6C). Furthermore, elimination of extracellular and intracellular ROS accumulation by NAC prevented the increase in the expression of CD95 by plasma treatment measured by flow cytometry, real-time PCR and western blotting (Figure 6D).
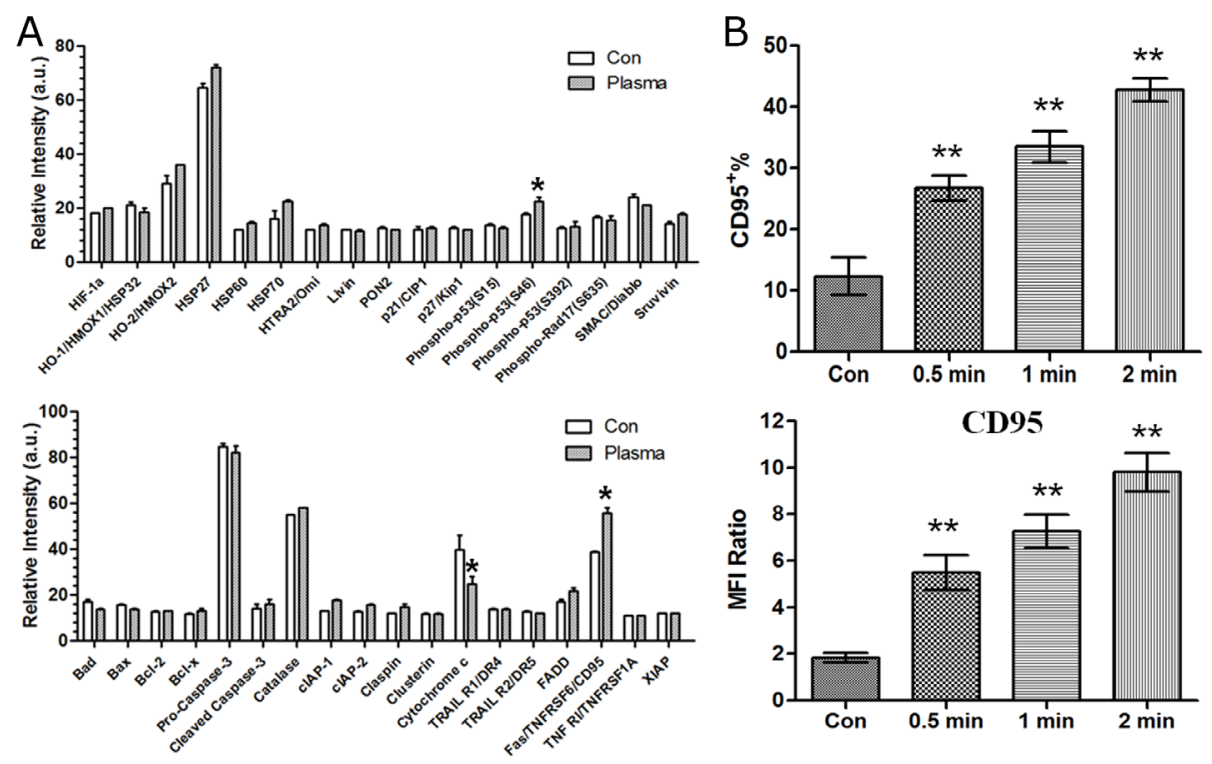

Figure 4: Analysis of apoptosis-related protein array and CD95 expression after plasma treatment. (A) Cell apoptotic apoptosis-related protein array detection was performed $24 \mathrm{~h}$ after $\mathrm{He}+\mathrm{O}_{2}$ plasma treatment for $1 \mathrm{~min}$. (B) CD95 expression was measured by flow cytometry $24 \mathrm{~h}$ after $\mathrm{He}+\mathrm{O}_{2}$ plasma treatment for $0.5 \mathrm{~min}, 1 \mathrm{~min}$ and $2 \mathrm{~min}$. IgG was used as the isotype control of CD95. Percentage of CD95 expression and MFI ratio were expressed in $\mathrm{M} \pm \mathrm{SD} .{ }^{*}$ indicates $\mathrm{p}<0.05,{ }^{* *}$ indicates $\mathrm{p}<0.01$ 


\section{p53 mediated CD95 up-regulation in plasma- induced apoptosis}

Using the apoptosis-related protein array we also detected an increase in phospho-p53 level after $\mathrm{He}+\mathrm{O}_{2}$ plasma treatment. In addition, several studies had reported that p53 was activated in response to plasma treatment and promoted cancer cell apoptosis [36-39]. We wondered whether $\mathrm{p} 53$ could regulate CD95 expression thus activating the downstream caspase pathway. PFT- $\alpha$, a p53 inhibitor, was used in this study and could reduce cell apoptosis by plasma treatment (Figure 7A). Western
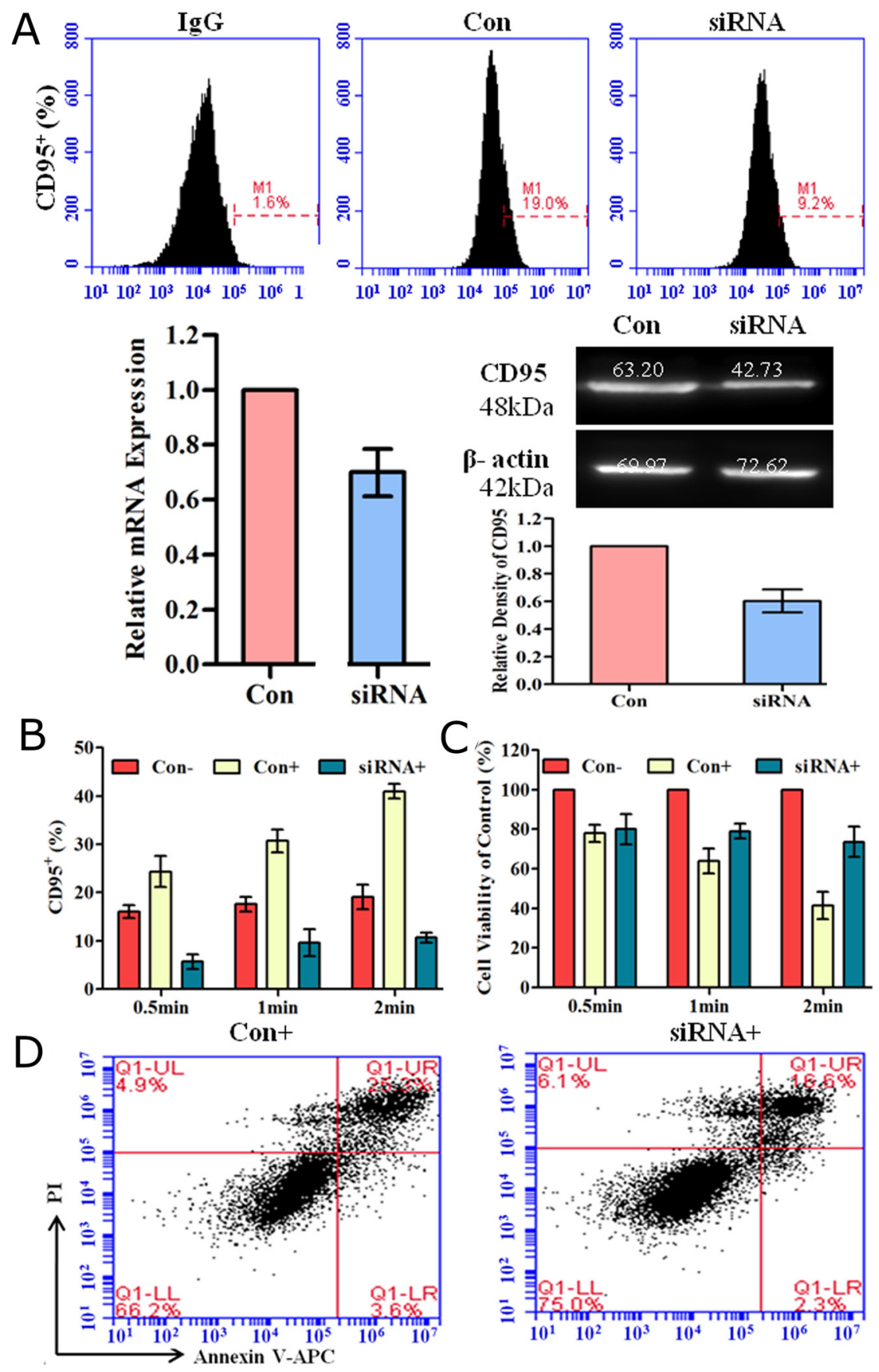

Figure 5: Down-regulation of CD95 expression by siRNA reduced plasma-induced cell apoptosis. (A) CD95 expression detected by flow cytometry, real-time PCR and western blotting after siRNA-mediated knockdown for $48 \mathrm{~h}$. IgG is the isotype control. Con indicates transfection of control scramble siRNA compared to CD95-targeting siRNA. (B, C) CD95 expression (B) and corresponding cell viability (C) $24 \mathrm{~h}$ after plasma treatment for $0.5 \mathrm{~min}, 1 \mathrm{~min}$ and $2 \mathrm{~min}$. Con- and Con+ groups were transfected with control scramble siRNA and treated without or with $\mathrm{He}+\mathrm{O}_{2}$ plasma. The siRNA ${ }^{+}$group represents cells treated with $\mathrm{He}^{+} \mathrm{O}_{2}$ plasma after knockdown of CD95 by siRNA. (D) Cell apoptosis was detected $24 \mathrm{~h}$ after $\mathrm{He}^{+} \mathrm{O}_{2}$ plasma treatment for 1 min following transfection. ${ }^{*}$ indicates $\mathrm{p}<0.05$. 
blotting showed that NAC and PFT- $\alpha$ could both decrease the expression of phospho-p53. Meanwhile, inhibition of p53 prevented the up-regulation of CD95 expression and the activation of caspase 3/8/9 detected by western blotting (Figure 7B). Since p53 is a transcription factor, using ChIP assay, we investigated whether p53 could bind to the promoter region of CD95 to regulate CD95 expression. Indeed, our ChIP results demonstrated that phospho-p53 could bind to the promoter region of CD95 mRNA and regulate mRNA expression, as a clear band was detected by electrophoresis in the sample treated with $\mathrm{He}+\mathrm{O}_{2}$ plasma (Figure $7 \mathrm{C}$ ). $\mathrm{He}+\mathrm{O}_{2}$ plasma increased the binding of p53 to the CD95 promoter region (-1454 upstream of the CD95 transcription initiation site) compared to the control and activated CD95 mRNA expression (Figure 7C). The details of sequence analysis are list in Supplementary Files (sequences analysis.doc).

\section{Differential expression of CD95 and sensitivity of normal and myeloma cells to plasma treatment in cell lines and clinical samples}

Since we demonstrated that CD95 is an important target in plasma-induced cell apoptosis, we wondered whether normal and tumor cells express different levels of CD95 and if the cells have differential sensitivity to plasma treatment. As shown in (Figure 8A), LP-1 myeloma cells have a higher expression of CD95 compared to normal cells (marrow stromal cells, MSC) detected by flow cytometry, real-time PCR and western blotting. Meanwhile, viability assay revealed that MM tumor cells were more sensitive to plasma treatment that MSC normal cells (Figure 8B). Similar to the data from MM cell lines, the tumor cells derived from MM patients displayed higher CD95 expression compared to
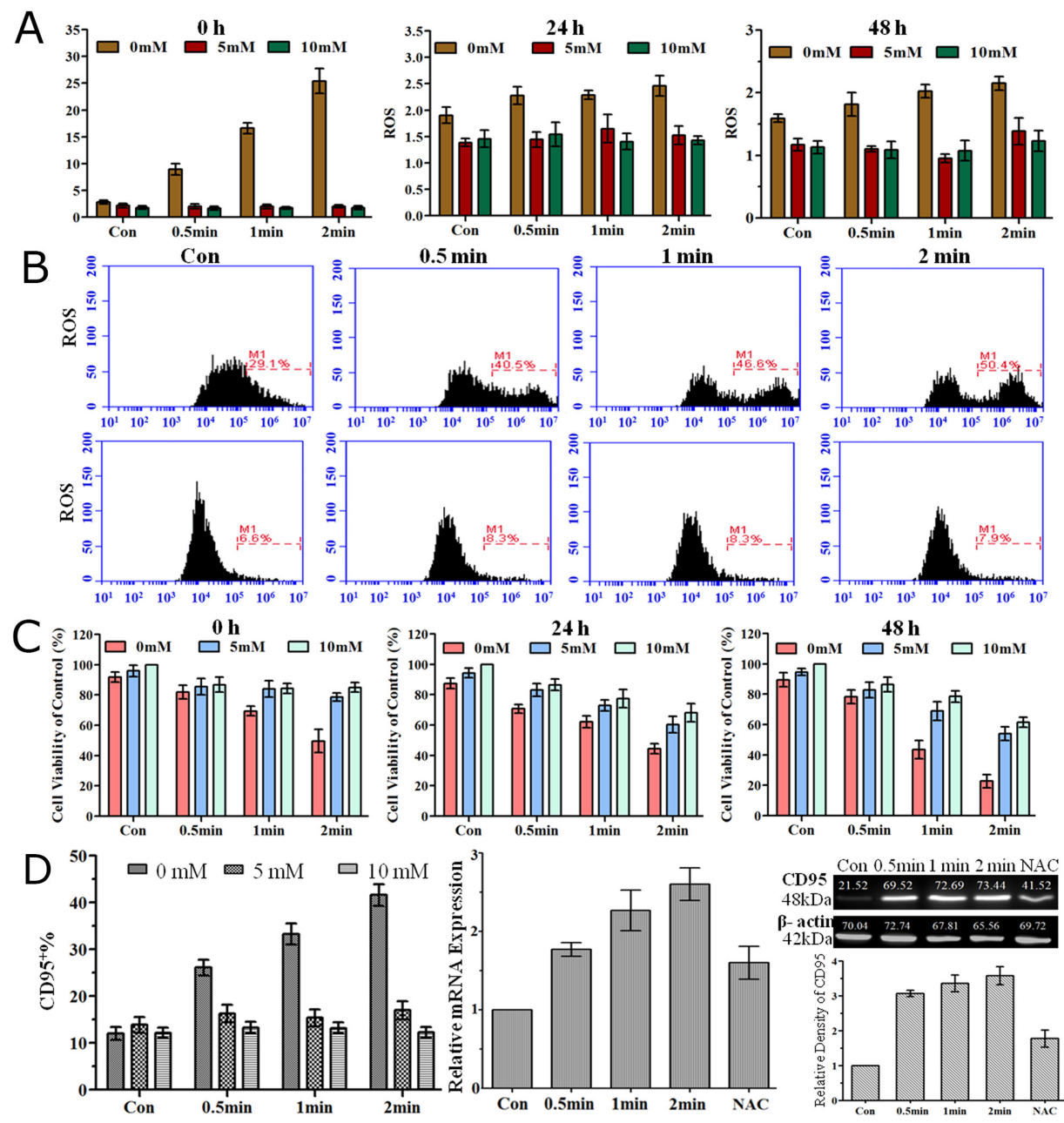

Figure 6: Extracellular and intracellular ROS, cell viability and CD95 expression were measured after $\mathrm{He}_{2}+\mathrm{O}_{2}$ plasma treatment with ROS scavenger (NAC). (A) Extracellular ROS level detected with a microplate reader at $0 \mathrm{~h}, 24 \mathrm{~h}$ and $48 \mathrm{~h}$ after plasma treatment for 0.5, 1 and 2 min with or without NAC. (B) Intracellular ROS level detected with a flow cytometer $24 \mathrm{~h}$ after plasma treatment without (above) or with (below) NAC. (C) Cell viability measured by CellTiter-Glo assay at $0 \mathrm{~h}, 24 \mathrm{~h}$ and $48 \mathrm{~h}$ after plasma treatment for 0.5, 1 and 2 min with or without NAC. (D) CD95 expression was detected by flow cytometry (left) and real-time PCR (middle) $24 \mathrm{~h}$ after $\mathrm{He}+\mathrm{O}_{2}$ treatment and by western blot (right) $48 \mathrm{~h}$ after plasma treatment with or without NAC. 
normal control detected by flow cytometry (Figure 8C) and western blotting (Figure 8D). In addition, the tumor cells showed a significant reduction in cell viability after plasma treatment compared to the normal control (Figure 8E). By fluorescent in situ hybridization (FISH), we detected several common genetic alterations in MM that could predict the prognosis of MM patients. Patients with RB1 deletion and 13q14 deletion were considered to have moderate prognosis, while patients with 1q21 amplification and $14 \mathrm{q} 32$ translocation were considered to have poor prognosis [35] (Supplementary Table 2). Interestingly, tumor cells derived from patients with poor prognosis were more sensitive to plasma treatment than those from patients with moderate prognosis (Figure 8F). Furthermore, we analyzed the viability differences of tumor cells and normal cells after plasma treatment and found that for the samples from patients with moderate prognosis, shorter plasma treatment (30 s) showed better selectivity, while that with poor prognosis, longer plasma treatment (60 s) showed better selectivity (Figure 8G). These data may provide useful treatment parameters for clinical therapy.

\section{DISCUSSION}

Plasmas are a mixture of charged particles, neutral gas molecules, UV radiation, and reactive species, among which, the reactive species were considered to be the most important factors for biological effects [40]. The temperature of plasma in our study is around $30^{\circ} \mathrm{C}$, which has little heat effect on cells as cells were further cultured at $37^{\circ} \mathrm{C}$ in the incubator. This plasma jet generation system was used in our previous studies and characters of the plasma generation and electronic parameters were well illustrated in our previous works, including the distribution of various species by emission spectrum and mass spectrometer [28]. We also demonstrated that plasma jet could generate aqueous reactive species including $\mathrm{OH}$, $\mathrm{H}_{2} \mathrm{O}_{2}, \mathrm{O}_{2}^{-}$and nitrite $\left(\mathrm{HNO}_{2} / \mathrm{NO}_{2}^{-}\right)$, among which the longlived species $\left(\mathrm{H}_{2} \mathrm{O}_{2}\right)$ could reach to $\mu \mathrm{M}$ concentration level $[41,42]$. In this study, we found for the first time that CD95/FAS is a pivotal target that induces cancer cell apoptosis in response to plasma treatment. The activation of CD95 was positively correlated with the accumulation of extracellular and intracellular ROS. Interestingly, there was
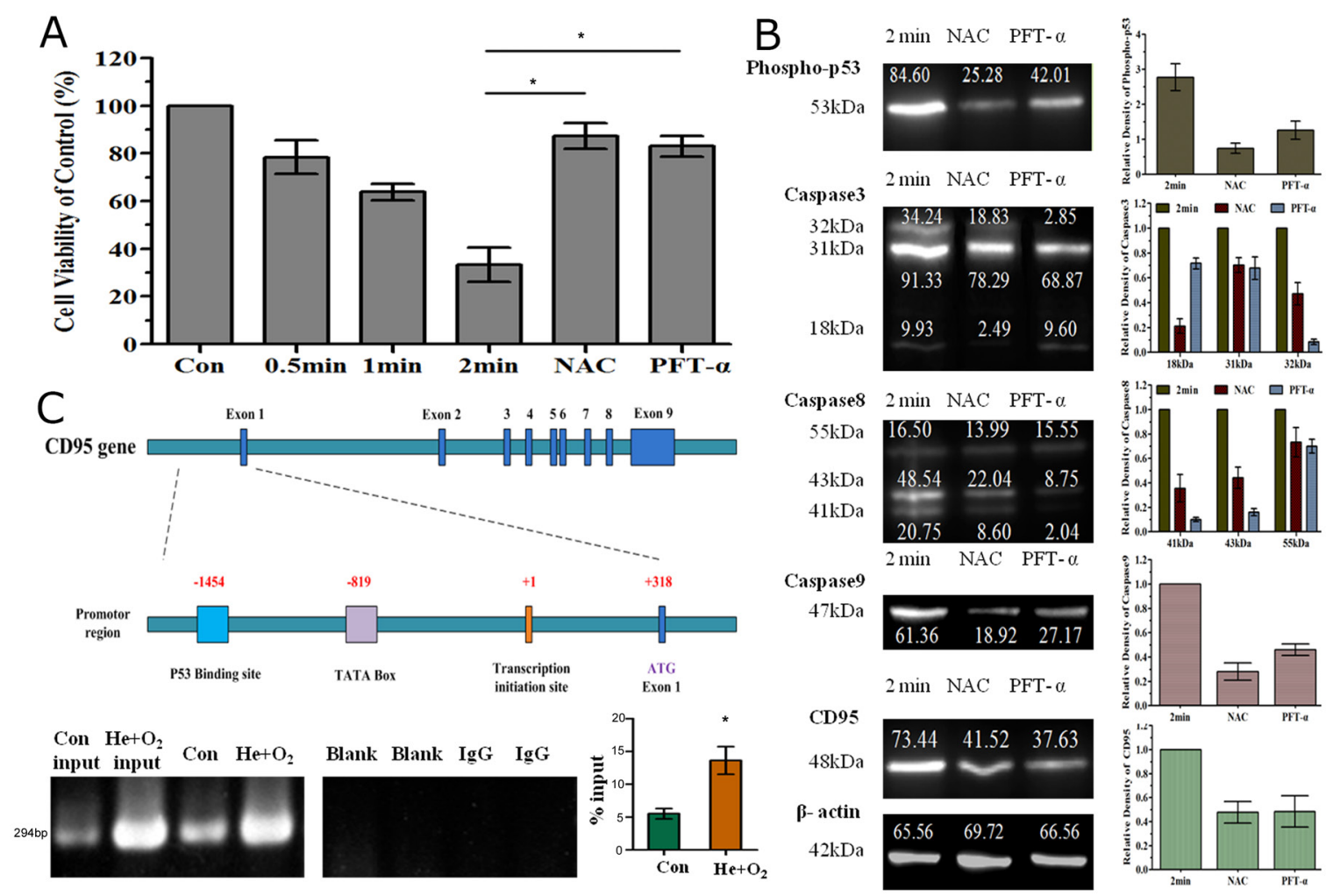

Figure 7: Involvement of p53 in CD95-mediated cell apoptosis by $\mathrm{He}+\mathrm{O}_{2}$ plasma treatment. (A) Analysis of cell viability after plasma treatment for $0.5,1$ and 2 min with or without NAC or PFT- $\alpha$ (p53 inhibitor). (B) Western blot analysis of phospho-p53, caspase 3/8/9 and CD95 expression after plasma treatment. NAC and PFT- $\alpha$ indicates that the ROS scavenger and p53 inhibitor were added respectively before plasma treatment for $2 \mathrm{~min}$. (C) Interaction of p53 and CD95 promoter region in response to plasma treatment. The top panel shows the illustration of the CD95 promoter region and p53 binding site. The bottom panel shows the results of ChIP assay for p53 and CD95 promoter detected by RT-PCR and real-time PCR. * indicates $\mathrm{p}<0.05$. 
a time lag between the increase in extracellular ROS and the accumulation of intracellular ROS, as the former was significantly increased immediately after plasma treatment, but the latter could only be detected $24 \mathrm{~h}$ after plasma treatment. Only some small molecules such as $\mathrm{H}_{2} \mathrm{O}_{2}$ can catalytically permeate cells with the aid of the membrane transporters [43]. However, other ROS, such as $\mathrm{OH}$ radicals, cannot pass through the cell membrane owing to their high reactivity. Therefore, most of the intracellular ROS are generated inside the cells through signal transduction from the extracellular ROS. This can explain the time lag for the detection of intracellular ROS $24 \mathrm{~h}$ after plasma treatment. However, details regarding signaling transduction by ROS are mostly unknown because of the high reactivity and extreme short life of ROS.

We used $\mathrm{He}+\mathrm{O}_{2}$ plasma in our study, as the addition of $\mathrm{O}_{2}$ can increase the production of ROS by plasma and cause more cell death. From the emission spectra, we confirmed that the $\mathrm{He}+\mathrm{O}_{2}$ plasma generated more ROS such as $\mathrm{OH}, \mathrm{O} 777$ and O845 compared to the He plasma. However, higher percentage of $\mathrm{O}_{2}$ in the $\mathrm{He}$ mixture can decrease plasma intensity or even inhibit plasma generation. Considering the plasma intensity and stability (monitored using electric current) along with its effects on cell viability, we chose the plasma generated from $\mathrm{He}+0.5 \% \mathrm{O}_{2}$ for our subsequent experiments. Several studies also reported that $\mathrm{He}+\mathrm{O}_{2}$ plasma could substantially reduce cancer cell viability $[44,45]$.

ROS production by other approaches (such as chemo-drugs) can also result in cell apoptosis through up-regulation of CD95, which has been reported in the literature $[16,46]$. Here, we demonstrated that ROS production by plasma treatment, could lead to cell apoptosis via the activation of CD95 and downstream caspase cascade. By down-regulation of CD95, we confirmed that CD95 is a major executor in plasma-
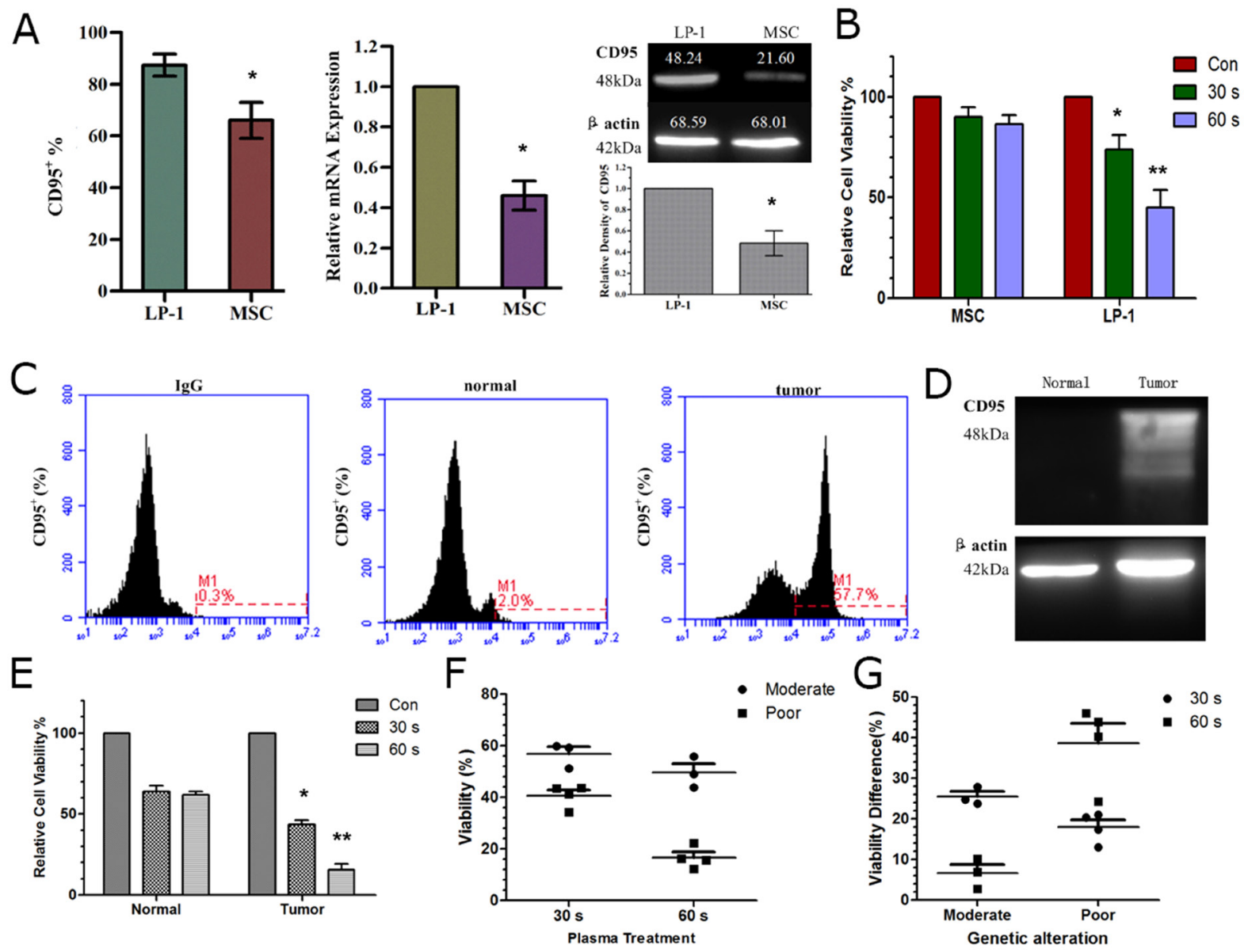

Figure 8: Differential CD95 expression and sensitivity to plasma of cell lines and patient samples. (A) CD95 expression in MM tumor cells and normal cells (MSC) detected by flow cytometry, real-time PCR and western blotting. (B) Sensitivity of tumor and normal cells to plasma treatment assessed by cell viability assay. (C, D) CD95 expression detected by flow cytometry (C) and western blotting (D) in a representative patient sample. (E) Sensitivity of tumor and normal cells derived from patients assessed by cell viability assay $24 \mathrm{~h}$ after plasma treatment. (F) Sensitivity of MM tumor cells derived from patients with moderate and poor prognosis (analyzed by FISH) in response to plasma treatment, (G) Difference in viability of tumor and normal cells after plasma treatment in samples from patients with moderate and poor prognoses. ${ }^{*}$ indicates $\mathrm{p}<0.05,{ }^{* *}$ indicates $\mathrm{p}<0.01$. 
induced cell apoptosis. However, whether the extracellular ROS can directly affect CD95 to activate the caspase cascade remains unknown. By far, computer modeling could be a way to understand the interaction of small molecules (especially with high reactivity) with biological molecules [47]. In our study, we could only demonstrate with an ROS scavenger that ROS accumulation is necessary for CD95 activation by plasma. Interestingly, we also detected an increase in phospho-p53 in the protein array. The tumor suppressor protein p53 is a redox-active transcription factor that regulates various downstream targets and can induce cell apoptosis [48]. As a secondary messenger, ROS can activate p53 expression, thereby regulating downstream targets of p53 [49, 50]. Zalcenstein et al. reported that in $\mathrm{H}_{2} \mathrm{O}_{2}$-treated human cells, one-third of the highly responsive genes were targets of p53 [51]. Therefore, we investigated whether CD95 up-regulation in response to plasma treatment was mediated by $\mathrm{p} 53$. Using anti-phospho-p53 antibodies, we isolated the DNA fragments bound to p53. With well-designed PCR primers against the CD95 promoter region, we observed a significant increase in interaction between p53 and CD95 promoter after $\mathrm{He}+\mathrm{O}_{2}$ plasma treatment. Furthermore, p53 inhibitor could reduce the up-regulation of CD95 induced by plasma treatment. Hence, for the first time, we reported the details of ROS/p53/CD95/caspase activation with a $\mathrm{He}+\mathrm{O}_{2}$ plasma treatment system. By ChIP assay, Ruiz et al. reported the presence of p53-mediated up-regulation of CD95 gene expression upon genotoxic treatment in human breast tumor cells, which was consistent with our results showing that p53 could interact with CD95 promoter, thereby regulating its mRNA expression [52].

Unlike radiation, which can penetrate deep inside tissues, CAP has limited penetration. For topological treatment such as in dermatology and wound healing, direct plasma treatment could be applied. For other internal diseases, injection of plasma-activated medium (PAM) could be used. Many studies have reported the induction of cell death by PAM in various tumor cells such as glioblastoma cells, lung adenocarcinoma cells and ovarian cancer cells [53-56]. Understanding the mechanism of plasma-induced myeloma cell death will provide a better strategy for future clinical trials investigating the injection PAM into the blood or bone marrow. However, before gas plasma could be applied in clinical cancer treatment, the safety should also be concerned. It is revealed that plasma treatment could selectively induce tumor cells apoptosis but had little cytotoxicity on normal cells $[53,57]$. Our previous study demonstrated that oral lavage of PAW treatment on immuno-deficient nude mice showed no significant safety problems without lethal effect and other acute toxicity [58]. Besides, some gas plasma devices have been applied in clinical trials, especially in wound healing $[59,60]$. Some products in plasma medicine have been certified by the U.S. Food and Drug Administration (FDA) [61], although they all limited in skin treatment. In this study, we detected that the myeloma cells were more sensitive to plasma treatment compared to the normal stromal cells (MSC). Since we demonstrated that CD95 is critical in plasma-induced apoptosis, we analyzed the differential expression of CD95 in cancer and normal cells. We found that CD95 expression was higher in tumor cells than in normal cells in both MM cell lines and clinical samples. Interestingly, we predicted prognosis by FISH to detect genetic alterations and found that cells from MM patients with poor prognosis were more sensitive to plasma treatment. This may partly be because patients with poor prognosis have a higher percentage of MM tumor cells in the bone marrow. These results further confirmed that CD95 could be a potential target for myeloma treatment with gas plasma.

In conclusion, we demonstrated that $\mathrm{He}+\mathrm{O}_{2}$ plasma could efficiently induce cell apoptosis through the activation of CD95 and downstream caspase cascades. Extracellular and intracellular ROS accumulation was essential for CD95-mediated cell apoptosis in response to plasma treatment. Furthermore, p53 was shown to be a key transcription factor in activating CD95 and caspase cascades. Supplementary Figure 2 illustrates the schematic representation of $\mathrm{He}+\mathrm{O}_{2}$ plasma-induced cell apoptosis mediated by ROS/p53/CD95/Caspase signaling. Meanwhile, we demonstrated that CD95 expression was higher in tumor cells than in normal cells in both MM cell lines and MM clinical samples, which suggests that CD95 could be a favorable target for plasma treatment as it could selectively inactivate myeloma tumor cells.

\section{MATERIALS AND METHODS}

\section{Plasma generation system}

The cold atmospheric plasma used in this study was generated using a plasma jet described in our previous study [62]. And the schematic diagram of the device structure is shown in Figure 1A. A $1 \mathrm{~mm}$ stainless steel needle as a powered electrode enclosed in a length of $6 \mathrm{~cm}$ and inner and outer diameters of $4 \mathrm{~mm}$ and $6 \mathrm{~mm}$ quartz tube respectively, which is $15 \mathrm{~mm}$ above the top of quartz tube. A length of $10 \mathrm{~mm}$ copper sheet was wrapped around the quartz tube at a distance of $10 \mathrm{~mm}$ from the nozzle end serves as the ground electrode. The plasma generation system included a gas flow controller, high-voltage power supply, oscilloscope, and plasma jet. A gas flow of 2 SLM was used for $\mathrm{He}$ at $10 \mathrm{kHz} / 8 \mathrm{kV}$. Additional $\mathrm{O}_{2}$ was added in the gas flow to generate $\mathrm{He}+\mathrm{O}_{2}$ plasma for more ROS production.

\section{Cell culture conditions}

The LP-1 multiple myeloma cells and MSC cells were used as control cells as described in our previous study [62]. These suspension cells were grown in 
Roswell Park Memorial Institute (RPMI) 1640 medium supplemented with $10 \%$ fetal calf serum, $100 \mathrm{U} / \mathrm{mL}$ penicillin, and $50 \mu \mathrm{g} / \mathrm{mL}$ streptomycin (Corning, Ithaca, NY, USA). The cells were cultured at $37^{\circ} \mathrm{C}$ in an incubator (Thermo Scientific, Waltham, MA, USA) containing 5\% $\mathrm{CO}_{2}$. The medium was refreshed $24 \mathrm{~h}$ before performing experiments, then $6 \times 10^{4}$ cells/ well in $100 \mu \mathrm{L}$ medium were seeded on 96-well plate and $2 \times 10^{5}$ cells/ well in $300 \mu \mathrm{L}$ medium were seeded on 24 -well plate when performing the plasma treatment experiments.

\section{Optical emission spectroscopy}

Emission spectra of the plasma were measured using a UV/Visible spectrometer (Maya pro 2000, Ocean Optics, China) within a wavelength range of 200-800 $\mathrm{nm}$. The emission spectra of He plasma with different percentage of $\mathrm{O}_{2}$ were analyzed in the vertical plane of the plasma jet. Because the intensity of light is highest at the point where the plasma touches air, the optical probe was mounted at the nozzle of the plasma jet generator, which guarantees a clear spectrum of particles in the plasma plume.

\section{Cell viability assay}

A Cell-Titer-Glo ${ }^{\circledR}$ luminescent cell viability assay kit (Promega, Madison, WI, USA) which based on the production of ATP in viable cells was used to measure cell viability. $100 \mu \mathrm{L}$ of samples and $100 \mu \mathrm{L}$ of Cell-Titer$\mathrm{Glo}^{\circledR}$ reagent were added to the opaque-walled multi-well plate, then the plate was incubated at room temperature for $10 \mathrm{~min}$ after mixing for $2 \mathrm{~min}$ on an orbital shaker. The luminescence was determined using the microplate reader ((Thermo Scientific Varioskan Flash, Waltham, MA, USA) with the protocol of "luminometric" measurement.

\section{Cell apoptosis assessment}

We used Annexin V and PI (BioLegend, San Diego, CA, USA) double staining for the detection of cell apoptosis by flow cytometry. After treatment with plasma for $24 \mathrm{~h}$, cells were washed twice with cell staining buffer and resuspended in $50 \mu \mathrm{L}$ Annexin $\mathrm{V}$ binding buffer. Next, $2 \mu \mathrm{L}$ Annexin V-APC and $2.5 \mu \mathrm{L}$ PI were added and incubated for $15 \mathrm{~min}$ at room temperature in the dark. Then, $400 \mu \mathrm{L}$ Annexin V binding buffer was added, followed by flow cytometry (Accuri C6; BD, USA).

\section{Detection of MMP}

Mitochondria staining kit (Sigma-Aldrich, Saint Louis, MO, USA), which contains the cationic lipophilic dye JC-1, was used to detect changes in the MMP in LP-1 cells after plasma treatment following the manufacturer's instruction. After incubation for $24 \mathrm{~h}, 1 \mathrm{~mL}$ LP-1 cell suspension $\left(1 \times 10^{6} / \mathrm{mL}\right)$ was collected from each treatment and mixed with $1 \mathrm{~mL}$ prepared staining solution with $\mathrm{JC}-1$ at a final concentration of $2.5 \mu \mathrm{g} / \mathrm{mL}$. The mixture was incubated for $20 \mathrm{~min}$ at $37^{\circ} \mathrm{C}$ in an incubator containing $5 \% \mathrm{CO}_{2}$. After washing with ice-cold $1 \times \mathrm{JC}-1$ staining buffer, the cells were resuspended in $0.5 \mathrm{~mL}$ staining buffer. The stained cells were observed by fluorescence microscopy (BX53; Olympus, Japan), following the step of concentrating the suspensions onto microslides by centrifugation for $15 \mathrm{~min}$ at $750 \mathrm{rpm}$ with a cytocentrifuge (Cytopro; Wescor, Logan, UT, USA), as well as analyzed directly by flow cytometry (BD). Valinomycin-treated cells were used as positive control, because valinomycin can dissipate the MMP in LP-1 cells.

\section{Stability of lysosomal membrane}

Lucifer yellow CH (Sigma-Aldrich, $2 \mathrm{mg} / \mathrm{ml}$ stock solution in PBS), which indicates the stability and leakage of lysosomes, wasadded to LP-cells at a final concentration of $100 \mu \mathrm{g} / \mathrm{ml}$ and incubated overnight. Then, the cells were washed three times with PBS and seeded on a 24-well plate. Next, the stained LP-cells were treated with plasma for $0 \mathrm{~min}$ (control group), $0.5 \mathrm{~min}, 1 \mathrm{~min}$ and $2 \mathrm{~min}$. After incubation for $24 \mathrm{~h}$, cells were washed twice and concentrated onto a glass slide using a cytocentrifuge (Cytopro; Wescor, Logan, UT, USA) for observation of the cell status via fluorescence microscopy (BX53; Olympus, Japan).

\section{Human apoptosis array kit}

Human Apoptosis Array Kit (R\&D Systems, Minneapolis, MN, USA), which can detect 35 different proteins like Bad, Bax, BCL-2, Fas and HSP27 etc., was purchased for analyzing the expression profiles of apoptosis-related proteins induced by plasma treatment for $1 \mathrm{~min}$. After $24 \mathrm{~h}$ incubation, LP-1 cells treated with or without plasma were rinsed with PBS and solubilized in lysis buffer 17 for $30 \mathrm{~min}$ at $4^{\circ} \mathrm{C}$, followed by centrifuging at 14,000 rpm for $5 \mathrm{~min}$, then the supernate was transferred and protein concentration was quantified. Cell lysates with $300 \mu \mathrm{g}$ protein was added and incubated overnight at $4^{\circ} \mathrm{C}$ after blocking membrane with array buffer 1 . Following washing each array with $1 \times$ wash buffer for 10 min twice, $1.5 \mathrm{~mL}$ of detection antibody cocktail was added and incubated $1 \mathrm{~h}$ on a rocking platform shaker. Then the array was washed and $2.0 \mathrm{~mL}$ of Streptavidin-HRP was pipetted into each well and incubated for $30 \mathrm{~min}$. After washing each array, the protein spots were visualized using Chemi Reagent Mix by Chemi-Doc-it Imaging System (UVP, Upland, CA, USA) and the intensity was determined by ImageJ Version 1.45 software.

\section{Analysis of CD95 expression by flow cytometry}

The expression of CD95 was assayed by immunofluorescence staining using flow cytometry. In brief, LP-1 cells were harvested and washed twice with PBS. 
Then, the cells were incubated with $5 \mu \mathrm{L}$ of CD95-FITC (BioLegend, San Diego, CA, USA) in $50 \mu \mathrm{L}$ PBS for $30 \mathrm{~min}$ at room temperature in the dark. After that, the cells were washed with PBS and resuspended in $400 \mu \mathrm{L}$ PBS for flow cytometric (C6) analysis. Mouse IgG1-FITC (Biolegend, San Diego, CA, USA) was used as an isotype control for CD95 in this experiment. The MFI (mean fluorescence intensity) ratio was determined as follows: $\mathrm{MFI}$ ratio $=$ MFI of CD95 expression / MFI of isotype control.

\section{Transfection with siRNA}

Lipofectamine 2000 was used to transfect CD95targeting siRNA into LP-1 cells to knock down the expression of CD95 following the manufacturer's instructions. Briefly, at the time of transfection, $1 \times 10^{5}$ cells/well were plated in 24-well plates with culture medium. For each sample, cells were transfected with CD95-targeting siRNA (Santa Cruz, CA, USA) at a final concentration of $125 \mathrm{nM}$ using $6 \mu \mathrm{L}$ of Lipofectamine 2000 reagent (Invitrogen, Carlsbad, CA, USA). A scramble siRNA was used as control siRNA. After incubation for $48 \mathrm{~h}$, cell viability and cell apoptosis were analyzed, and CD95 expression was determined by real-time PCR, WB and flow cytometry as mentioned. Then, the cells were treated with plasma for further experiments.

\section{Detection of ROS}

In our experiment, CMH2-DCFDA (Invitrogen, Grand Island, NY, USA) was used to detect ROS concentration. Cells $\left(1 \times 10^{5}\right)$ were plated in 24 -well plates with $300 \mu \mathrm{L}$ complete medium and treated with plasma for $0.5 \mathrm{~min}, 1 \mathrm{~min}$ and $2 \mathrm{~min}$ with or without $5 \mathrm{mM} / 10 \mathrm{mM}$ NAC. After $24 \mathrm{~h}, 10 \mu \mathrm{M}$ of CMH2-DCFDA was incubated with the LP- 1 cells for $30 \mathrm{~min}$ at $37^{\circ} \mathrm{C}$. Extracellular ROS was measured with a microplate reader (Thermo Scientific) with excitation/emission at 485/530 $\mathrm{nm}$ using the protocol for "Fluorometric" measurement. Then, the cells were washed three times with PBS and collected for analysis of intracellular ROS using a flow cytometer (Accuri C6).

\section{Enzyme activity of caspase3/8/9}

Caspase colorimetric assay kit (Biovision, USA) was used to evaluate caspase activity in LP-1 cells treated with plasma for $0.5 \mathrm{~min}, 1 \mathrm{~min}$ and $2 \mathrm{~min}$. NAC was added to the cells at a final concentration of $10 \mathrm{mM}$ followed by 2 min plasma treatment. After incubation for $6 \mathrm{~h}$ and $9 \mathrm{~h}$, cells were resuspended in $50 \mu \mathrm{L}$ cell lysis buffer and incubated on ice for $10 \mathrm{~min}$. Then, the concentration of protein in the centrifuged supernatant was assayed. Samples with 150 $\mu \mathrm{g}$ protein in $50 \mu \mathrm{L}$ cell lysis buffer were added to 96 -well plates and cultured with $50 \mu \mathrm{L}$ of $10 \mathrm{mM}$ DTT and $5 \mu \mathrm{L}$ of $4 \mathrm{mM}$ substrate at $37^{\circ} \mathrm{C}$ for $1.5 \mathrm{~h}$. The absorbance was read at $400 \mathrm{~nm}$ in a microtiter plate reader (Thermo Scientific).

\section{Western blot}

After plasma treatment for $48 \mathrm{~h}$, cell protein was extracted using RIPA lysis buffer (Sigma), and the concentration was determined by BCA protein assay kit (Sigma). Protein samples were denatured with $5 \times$ protein loading buffer at $95^{\circ} \mathrm{C}$ for $5 \mathrm{~min}$ and separated in $12.5 \%$ sodium dodecyl sulfate-polyacrylamide gel electrophoresis (SDS-PAGE) (Bio-Rad, Hercules, CA, USA). Subsequently, proteins were transferred to 0.2 $\mu \mathrm{m}$ of polyvinylidene difluoride membranes (Millpore, Billerica, MA, USA) at $70 \mathrm{~V}$ for $2.5 \mathrm{~h}$. After blocking with $5 \%$ non-fat milk for $2 \mathrm{~h}$ at room temperature, the membrane was incubated with primary antibody and then washed with TBST three times. The horseradish peroxidase (HRP)-conjugated secondary antibodies, goat anti-rabbit IgG and anti-mouse $\operatorname{IgG}(1: 2000)$ (Abgent, San Diego, CA, USA), were added and incubated for $1 \mathrm{~h}$ on a horizontal orbital shaker. Images were visualized with ECL chemiluminescent substrate (Millipore, Bedford, MA, USA) using a ChemiDoc-It 510 system (UVP, Upland, CA, USA) and protein bands were analyzed by densitometric analysis using ImageJ software. Primary antibody against human included caspase-3 (1:500), caspase-8 (1:500), caspase-9 (1:500), phospho-p53 (1:200) (Cell Signaling Technology, Danvers, MA, USA), CD95 (1:200) (Santa Cruz, CA, USA) and $\beta$-actin $(1: 1000)$ (Immuno Way, Newark, DE, USA).

\section{Real-time PCR}

To quantify the relative mRNA expression of CD95 (Fas), real-time PCR was performed after plasma treatment $(24 \mathrm{~h}$ later $)$ or siRNA trasfection (48 h later). Total RNA was extracted from LP-1 cells using EZNA total RNA kit II (Omega Bio-Tec Inc., Doraville, GA, USA). After quantifying with Nano Drop spectrophotometry (BioTek ${ }^{\circledR}$ Instruments Inc., Winooski, VT, USA), $2 \mu \mathrm{g}$ of total RNA was used for the synthesis of fist strand cDNA using RevertAid first strand cDNA synthesis kit (Thermo Scientific, Waltham, MA, USA), which performed on Applied Biosystems Veriti ${ }^{\mathrm{TM}}$ Thermal Cycler (Applied Biosystems, Foster City, CA, USA). All real-time PCR reactions were set up in a $20 \mu \mathrm{L}$ mixture containing 1/2 volume of $2 \times$ QuantiFast SYBR Green PCR MasterMix (Qiagen, Hilden, NRW, Germany), $0.5 \mu \mathrm{M}$ of primer, $1 \mu \mathrm{L}$ of cDNA templates and $8 \mu \mathrm{L}$ of DNAase-RNase Free water. The above reactions were run on Bio-Rad CFX Connect ${ }^{\mathrm{TM}}$ Real-time System (Bio-Rad, Foster City, CA, USA) and amplified with a optimized cycling condition: $5 \mathrm{~min}$ at $95^{\circ} \mathrm{C}$, then $10 \mathrm{~s}$ at $95^{\circ} \mathrm{C}$ and $30 \mathrm{~s}$ at $60^{\circ} \mathrm{C}$ for 38 cycles; the melting curves were obtained by slow heating $\left(0.5^{\circ} \mathrm{C} / \mathrm{s}\right)$ from $60^{\circ} \mathrm{C}$ to $95^{\circ} \mathrm{C}$. The primers were designed by Shenggong Company (Shanghai, China) and the sequences were showed below: 
Fas forward, 5'-CCCAGAATACCAAGTGCAG-3'; Fas reverse, 5'-GTGCATTCCTTGATGATTCCA-3'; $\beta$-actin forward, 5'-CATGTACGTTGCTATCCAGGC-3'; $\beta$-actin reverse, 5'-CTCCTTAATGTCACGCACGAT-3'. The relative expression of CD95 was normalized against a housekeeping gene of $\beta$-actin using the ${ }^{\Delta \Delta} \mathrm{Ct}$ method.

\section{Effect of p53 inhibitor Pifithrin- $\alpha$ on CD95 expression and plasma-induced cell apoptosis}

LP- 1 cells $\left(1 \times 10^{5} /\right.$ well $)$ were seeded in 24 -well plates with $300 \mu \mathrm{L}$ RPMI 1640 medium and pretreated with 10 $\mu \mathrm{M}$ of PFT- $\alpha$ (Target Mol, Boston, MA, USA), which is an inhibitor of $\mathrm{p} 53$, for $1 \mathrm{~h}$ at $37^{\circ} \mathrm{C}$ prior to treatment for 2 min with plasma. After incubation for $48 \mathrm{~h}$, apoptosis was examined by western blotting as previously described.

\section{ChIP assay}

ChIP assay was performed on LP-1 cells with Magna ChIPTM A/G (Millipore; Billerica, MA, USA) following the manufacturer's instructions. Cells $\left(1 \times 10^{6}\right)$ were treated with or without (control group) $\mathrm{He}+\mathrm{O}_{2}$ plasma for $1 \mathrm{~min}$; after incubation for $24 \mathrm{~h}$, cells were collected and fixed in $1 \%$ formaldehyde for cross-linking. The mixture was incubated at room temperature for $10 \mathrm{~min}$, and $10 \times$ Glycine was added to quench the unreacted formaldehyde. After incubation for $5 \mathrm{~min}$, the cells were centrifuged and washed twice with cold $1 \times$ PBS. The cell pellet was incubated with $0.5 \mathrm{~mL}$ of cell lysis buffer containing $1 \times$ protease inhibitor cocktail II for $15 \mathrm{~min}$ on ice. Then, the chromatin was isolated by adding $0.5 \mathrm{~mL}$ of nuclear lysis buffer containing $1 \times$ protease inhibitor cocktail II, followed by sonication to obtain sheared DNA. Chromatin DNA fragments were diluted in $450 \mu \mathrm{L}$ of dilution buffer containing protease inhibitor cocktail II and precipitated with antibodies against phospho-p53 (1:100) (Cell Signaling Technology) or isotype control IgG including 20 $\mu \mathrm{L}$ of fully resuspended protein $\mathrm{A} / \mathrm{G}$ magnetic beads at $4^{\circ} \mathrm{C}$ overnight with rotation. Protein $\mathrm{A} / \mathrm{G}$ magnetic beads were precipitated with a magnetic separator and washed with low salt, high salt, $\mathrm{LiCl}$ and TE Wash Buffer in sequence. Next, the cross-linked protein/DNA complexes were reversed to free DNA by incubating at $62^{\circ} \mathrm{C}$ for $2 \mathrm{~h}$ with shaking in the presence of $100 \mu \mathrm{L}$ of ChIP elution buffer and $1 \mu \mathrm{L}$ of proteinase $\mathrm{K}$ followed by incubation at $95^{\circ} \mathrm{C}$ for 10 min. Then, DNA was purified and used as a template for PCR and real-time PCR using the following primer pairs: 5'-GGATAATTAGACGTACGTGGGC-3' (forward) and 5'-GGACAATTGACAAAATCAGTATC-3' (reverse) [63]. The PCR products were detected on a $2 \%$ agarose gel.

\section{Preparation and analysis of MM clinical samples}

Seven newly diagnosed MM patients were chosen from the Department of Hematology, Xijing Hospital of
Xi'an. The basic information on these patients is listed in Supplementary Table 1, including gender, age and blood test results. Bone marrow samples were also obtained and tested using Giemsa staining to measure the percentage of MM tumor cells. MM tumor cells were sorted using MACS (magnetic-activated cell sorting) from the bone marrow samples. Briefly, $20 \mathrm{~mL}$ bone marrow (with heparin) was centrifuged and washed with PBS and resuspended in $7 \mathrm{~mL}$ of Ficoll (lymphocyte separation medium). The cells were centrifuged at $1800 \mathrm{rpm}$ for 20 min, and the middle layer was isolated for staining with CD138-conjugated magnetic beads. After incubation at $4^{\circ} \mathrm{C}$ for $15 \mathrm{~min}$, the cells were washed with PBS and sorted with MACS columns. The positively selected cells were considered MM tumor cells, and the rest of the cells mostly were bone marrow stromal cells that were considered as the control group. The sensitivity treatment of these cells to plasma was detected by a cell viability assay, and CD95 expression was measured by flow cytometry and western blotting.

\section{Genetic alterations in MM patients detected by FISH}

To evaluate the prognosis of MM patients, a FISH kit was used to detect gene abnormalities in MM. The kit can detect several common genetic abnormalities in MM, including RB1 deletion, 13q14 deletion, 1q21 amplification and $14 \mathrm{q} 32$ translocation (Supplementary Table 2). FISH was performed according to the manufacturer's instructions; the results were analyzed using the ratio of the number of positive cells to the total number of cells (counting for more than 200).

\section{Statistical analysis}

All samples were prepared in triplicate, and experiments were repeated at least three times. The data are presented as the means $\pm \mathrm{SD}$. Differences between groups were evaluated using one-way ANOVA and Student's $T$ test. $\mathrm{P}<0.05$ was considered statistically significant.

\section{Abbreviations}

MM: Multiple myeloma; PCs: Plasma cells; BM: bone marrow; ROS: Reactive oxygen species; DR: Death receptors; TNF: Tumor necrosis factor receptor; ER: Rndoplasmic reticulum; CAP: Cold atmospheric plasma; MMP: Mitochondrial membrane potential; PAM: Plasma-activated medium; MSC: Marrow stromal cells; DBD: Dielectric barrier discharger; FDA: Food and drug administration; RPMI: Roswell Park Memorial Institute; siRNA: Short interfering RNAs; MFI: Mean fluorescence intensity; SDS-PAGE: Sodium dodecyl sulfatepolyacrylamide gel electrophoresis; HRP: Horseradish 
peroxidase; ChIP: Chromatin immunoprecipitation; MACS: Magnetic-activated cell sorting; FISH: Fluorescent in situ hybridization.

\section{Author contributions}

DHX and YJX contributed equally to this work, performing experiments, analyzing the data, and writing the manuscript; DHX and MGK conceived and supervised the study; QJC participated in the experiment work; MJF and RL provided patient samples and assayed the genetic alterations; DXL, ZJL and XHW contributed to the visuals of this study. YJY, YK and HLC provided assistance and revised this manuscript.

\section{CONFLICTS OF INTEREST}

The authors declare no conflicts of interest.

\section{FUNDING}

This research was supported by the National Natural Science Foundation of China (grant nos. 51307135 and 51221005), China Postdoctoral Science Foundation (2017M610639), the Fundamental Research Funds for Central Universities, Special Fund of Shaanxi Postdoctoral Science Foundation and National Thousand Talents Program.

\section{REFERENCES}

1. Podar K, Chauhan D, Anderson KC. Bone marrow microenvironment and the identification of new targets for myeloma therapy. Leukemia. 2009; 23:10-24.

2. Ludwig H, Miguel J, Dimopoulos M, Palumbo A, Sanz RG, Powles R, Lentzsch S, Chen WM, Hou J, Jurczyszyn A. International myeloma working group recommendations for global myeloma care. Leukemia. 2014; 28:981-992.

3. Ocio EM, Richardson PG, Rajkumar SV, Palumbo A, Mateos MV, Orlowski R, Kumar S, Usmani S, Roodman D, Niesvizky R. New drugs and novel mechanisms of action in multiple myeloma in 2013: A report from the International Myeloma Working Group (IMWG). Leukemia. 2014; 28:525-542.

4. Laubach J, Garderet L, Mahindra A, Gahrton G, Caers J, Sezer O, Voorhees P, Leleu X, Johnsen H, Streetly M. Management of relapsed multiple myeloma: recommendations of the International Myeloma Working Group. Leukemia. 2016; 30:1005-1017.

5. Trachootham D, Alexandre J, Huang P. Targeting cancer cells by ROS-mediated mechanisms: a radical therapeutic approach? Nature reviews Drug discovery. 2009; 8:579-591.

6. Pelicano H, Carney D, Huang P. ROS stress in cancer cells and therapeutic implications. Drug Resistance Updates. 2004; 7:97-110.
7. Wason MS, Colon J, Das S, Seal S, Turkson J, Zhao J, Baker CH. Sensitization of pancreatic cancer cells to radiation by cerium oxide nanoparticle-induced ROS production. Nanomedicine: Nanotechnology, Biology and Medicine. 2013; 9:558-569.

8. Park MT, Kim MJ, Kang YH, Choi SY, Lee JH, Choi JA, Kang CM, Cho CK, Kang S, Bae S. Phytosphingosine in combination with ionizing radiation enhances apoptotic cell death in radiation-resistant cancer cells through ROSdependent and-independent AIF release. Blood. 2005; 105:1724-1733.

9. Hengartner MO. The biochemistry of apoptosis. Nature. 2000; 407:770-776.

10. Green DR, Kroemer G. The pathophysiology of mitochondrial cell death. Science. 2004; 305:626-629.

11. Elmore S. Apoptosis: a review of programmed cell death. Toxicologic pathology. 2007; 35:495-516.

12. Martin-Villalba A, Llorens-Bobadilla E, Wollny D. CD95 in cancer: tool or target? Trends in molecular medicine. 2013; 19:329-335.

13. Shima Y, Nishimoto N, Ogata A, Fujii Y, Yoshizaki K, Kishimoto T. Myeloma cells express Fas antigen/APO-1 (CD95) but only some are sensitive to anti-Fas antibody resulting in apoptosis. Blood. 1995; 85:757-764.

14. Villunger A, Egle A, Marschitz I, Kos M, Böck G, Ludwig H, Geley S, Kofler R, Greil R. Constitutive expression of fas (Apo-1/CD95) ligand on multiple myeloma cells: a potential mechanism of tumor-induced suppression of immune surveillance. Blood. 1997; 90:12-20.

15. Shima Y, Nishimoto N, Ogata A, Fujii Y, Yoshizaki K, Kishimoto T. Myeloma cells express Fas antigen/APO-1 (CD95) but only some are sensitive to anti-Fas antibody resulting in apoptosis. Blood. 1995; 85:757-764.

16. Woo SH, Park IC, Park MJ, An S, Lee HC, Jin HO, Park S, Cho H, Lee SJ, Gwak HS. Arsenic trioxide sensitizes CD95/ Fas-induced apoptosis through ROS-mediated upregulation of CD95/Fas by NF- $\kappa$ B activation. International Journal of Cancer. 2004; 112:596-606.

17. Dumont A, Hehner SP, Hofmann TG, Ueffing M, Droge W, Schmitz ML. Hydrogen peroxide-induced apoptosis is cd95-independent, requires the release of mitochondriaderived reactive oxygen species and the activation of NF-kappaB. Oncogene. 1999; 18:747-757.

18. Vandamme M, Robert E, Lerondel S, Sarron V, Ries D, Dozias S, Sobilo J, Gosset D, Kieda C, Legrain B. ROS implication in a new antitumor strategy based on nonthermal plasma. International Journal of Cancer. 2012; 130:2185-2194.

19. Graves DB. Mechanisms of plasma medicine: coupling plasma physics, biochemistry, and biology. IEEE Transactions on Radiation and Plasma Medical Sciences. 2017; 1:281-292.

20. Graves D, Hamaguchi S, O'Connell D. In Focus: plasma medicine. Biointerphases. 2015; 10:029301. 
21. Gweon B, Kim K, Choe W, Shin JH. (2016). Therapeutic uses of atmospheric pressure plasma: cancer and wound. biomedical engineering: frontier research and converging technologies: springer), pp. 357-385.

22. Fridman G, Friedman G, Gutsol A, Shekhter AB, Vasilets VN, Fridman A. Applied plasma medicine. Plasma Processes and Polymers. 2008; 5:503-533.

23. Shao T, Wang L, Zhang C, Zhou Y, Han L, Xu X, Schamiloglu E. A compact microsecond-pulse generator used for surface dielectric barrier discharges. IEEE Transactions on Plasma Science. 2016; 44:2072-2078.

24. Shao T, Zhang C, Wang R, Zhou Y, Xie Q, Fang Z. Comparison of atmospheric-pressure he and ar plasma jets driven by microsecond pulses. IEEE Transactions on Plasma Science. 2015; 43:726-732.

25. Wu S, Huang G, Cheng W, Chen W, Hai B, Shao T, Zhang C. The influences of the electrode dimension and the dielectric material on the breakdown characteristics of coplanar dielectric barrier discharge in ambient air. Plasma Processes and Polymers. 2017; 12:e201700112.

26. Brulle L, Vandamme M, Ries D, Martel E, Robert E, Lerondel S, Trichet V, Richard S, Pouvesle JM, Le Pape A. Effects of a non thermal plasma treatment alone or in combination with gemcitabine in a MIA PaCa2-luc orthotopic pancreatic carcinoma model. PLoS One. 2012; 7:e52653.

27. Walk RM, Snyder JA, Srinivasan P, Kirsch J, Diaz SO, Blanco FC, Shashurin A, Keidar M, Sandler AD. Cold atmospheric plasma for the ablative treatment of neuroblastoma. Journal of Pediatric Surgery. 2013; 48:67-73.

28. Xu D, Luo X, Xu Y, Cui Q, Yang Y, Liu D, Chen H, Kong MG. The effects of cold atmospheric plasma on cell adhesion, differentiation, migration, apoptosis and drug sensitivity of multiple myeloma. Biochemical and Biophysical Research Communiactions. 2016; 473:1125-1132.

29. Keidar M, Shashurin A, Volotskova O, Stepp MA, Srinivasan P, Sandler A, Trink B. Cold atmospheric plasma in cancer therapy. Physics of Plasmas. 2013; 20:057101.

30. Yan D, Sherman JH, Keidar M. Cold atmospheric plasma, a novel promising anti-cancer treatment modality. Oncotarget. 2017; 8:15977-15995. https://doi.org/10.18632/ oncotarget. 13304.

31. Choi JY, Joh HM, Park JM, Kim MJ, Chung TH, Kang TH. Non-thermal plasma-induced apoptosis is modulated by ATR-and PARP1-mediated dna damage responses and circadian clock. Oncotarget. 2016; 7:32980. https://doi. org/10.18632/oncotarget.9087.

32. Han I, Choi EH. The role of non-thermal atmospheric pressure biocompatible plasma in the differentiation of osteoblastic precursor cells, MC3T3-E1. Oncotarget. 2017; 8:36399. https://doi.org/10.18632/oncotarget.16821.

33. Ishaq M, Evans M, Ostrikov K. Effect of atmospheric gas plasmas on cancer cell signaling. International Journal Of Cancer. 2014; 134:1517-1528.
34. Machala Z, Janda M, Hensel K, Jedlovský I, Leštinská L, Foltin V, Martišovitš V, Morvova M. Emission spectroscopy of atmospheric pressure plasmas for bio-medical and environmental applications. Journal of Molecular Spectroscopy. 2007; 243:194-201.

35. van der Horst RM, Verreycken T, Van Veldhuizen E, Bruggeman P. Time-resolved optical emission spectroscopy of nanosecond pulsed discharges in atmospheric-pressure $\mathrm{N}_{2}$ and $\mathrm{N}_{2} / \mathrm{H}_{2} \mathrm{O}$ mixtures. Journal of Physics D: Applied Physics. 2012; 45:345201.

36. Chang JW, Kang SU, Shin YS, Kim KI, Seo SJ, Yang SS, Lee JS, Moon E, Baek SJ, Lee K. Non-thermal atmospheric pressure plasma induces apoptosis in oral cavity squamous cell carcinoma: Involvement of DNA-damage-triggering sub-G 1 arrest via the ATM/p53 pathway. Archives of biochemistry and biophysics. 2014; 545:133-140.

37. Joh HM, Choi JY, Kim SJ, Chung T, Kang TH. Effect of additive oxygen gas on cellular response of lung cancer cells induced by atmospheric pressure helium plasma jet. Scientific reports. 2014; 4:6638.

38. Ma Y, Ha CS, Hwang SW, Lee HJ, Kim GC, Lee KW, Song $\mathrm{K}$. Non-thermal atmospheric pressure plasma preferentially induces apoptosis in p53-mutated cancer cells by activating ROS stress-response pathways. PLoS One. 2014; 9:e91947.

39. Hou J, Ma J, Yu K, Li W, Cheng C, Bao L, Han W. Nonthermal plasma treatment altered gene expression profiling in non-small-cell lung cancer a549 cells. BMC Genomics. 2015; 16:435.

40. Lu X, Naidis GV, Laroussi M, Reuter S, Graves DB, Ostrikov K. Reactive species in non-equilibrium atmospheric-pressure plasmas: generation, transport, and biological effects. Physics Reports. 2016; 630:1-84.

41. Xu H, Chen C, Liu D, Xu D, Liu Z, Wang X, Kong MG. Contrasting characteristics of aqueous reactive species induced by cross-field and linear-field plasma jets. Journal of Physics D: Applied Physics. 2017; 50:245201.

42. He T, Liu D, Liu Z, Liu Z, Li Q, Rong M, Kong MG. The mechanism of plasma-assisted penetration of NO2- in model tissues. Applied Physics Letters. 2017; 111:203702.

43. Bienert GP, Schjoerring JK, Jahn TP. Membrane transport of hydrogen peroxide. Biochimica et Biophysica Acta. 2006; 1758:994-1003.

44. Walk RM, Snyder JA, Srinivasan P, Kirsch J, Diaz SO, Blanco FC, Shashurin A, Keidar M, Sandler AD. Cold atmospheric plasma for the ablative treatment of neuroblastoma. Journal of pediatric surgery. 2013; 48:67-73.

45. Gweon B, Kim M, Kim DB, Kim D, Kim H, Jung H, Shin JH, Choe W. Differential responses of human liver cancer and normal cells to atmospheric pressure plasma. Applied Physics Letters. 2011; 99:063701.

46. Simon HU, Haj-Yehia A, Levi-Schaffer F. Role of reactive oxygen species (ROS) in apoptosis induction. Apoptosis. 2000; 5:415-418. 
47. Chen C, Liu D, Liu Z, Yang A, Chen H, Shama G, Kong M. A model of plasma-biofilm and plasma-tissue interactions at ambient pressure. Plasma Chemistry and Plasma Processing. 2014; 34:403-441.

48. Polyak K, Xia Y, Zweier JL, Kinzler KW, Vogelstein B. A model for p53-induced apoptosis. Nature. 1997; 389:300-305.

49. Liu B, Chen Y, St Clair DK. ROS and p53: a versatile partnership. Free Radical Biology and Medicine. 2008; 44:1529-1535.

50. Catalano A, Rodilossi S, Caprari P, Coppola V, Procopio A. 5-Lipoxygenase regulates senescence-like growth arrest by promoting ROS-dependent p53 activation. The EMBO journal. 2005; 24:170-179.

51. Desaint S, Luriau S, Aude JC, Rousselet G, Toledano MB. Mammalian antioxidant defenses are not inducible by H2O2. Journal of Biological Chemistry. 2004; 279:31157-31163.

52. Ruiz-Ruiz C, Robledo G, Cano E, Redondo JM, LopezRivas A. Characterization of p53-mediated up-regulation of CD95 gene expression upon genotoxic treatment in human breast tumor cells. Journal of Biological Chemistry. 2003; 278:31667-31675.

53. Tanaka H, Mizuno M, Ishikawa K, Nakamura K, Kajiyama H, Kano H, Kikkawa F, Hori M. Plasma-activated medium selectively kills glioblastoma brain tumor cells by downregulating a survival signaling molecule, Akt kinase. Plasma Medicine. 2011; 1:265-277.

54. Adachi T, Tanaka H, Nonomura S, Hara H, Kondo SI, Hori M. Plasma-activated medium induces A549 cell injury via a spiral apoptotic cascade involving the mitochondrialnuclear network. Free Radical Biology and Medicine. 2015; 79:28-44.

55. Torii K, Yamada S, Nakamura K, Tanaka H, Kajiyama H, Tanahashi K, Iwata N, Kanda M, Kobayashi D, Tanaka C.
Effectiveness of plasma treatment on gastric cancer cells. Gastric cancer. 2015; 18:635-643.

56. Utsumi F, Kajiyama H, Nakamura K, Tanaka H, Mizuno M, Toyokuni S, Hori M, Kikkawa F. Variable susceptibility of ovarian cancer cells to non-thermal plasma-activated medium. Oncology reports. 2016; 35:3169.

57. Sandler A, Shashurin A, Trink B, Keidar M, Srinivasan P, Guerrero-Preston R, Ravi R, Walk R, Dasgupta S. Cold plasma selectivity and the possibility of a paradigm shift in cancer therapy. British journal of cancer. 2011; 105:1295.

58. Xu D, Cui Q, Xu Y, Wang B, Tian M, Li Q, Liu Z, Liu D, Chen H, Kong MG. Systemic study on the safety of immuno-deficient nude mice treated by atmospheric plasma activated water. Plasma Science and Technology. 2018; 20.

59. Haertel B, von Woedtke T, Weltmann KD, Lindequist U. Non-thermal atmospheric-pressure plasma possible application in wound healing. Biomolecules \& therapeutics. $2014 ; 22: 477$.

60. Lloyd G, Friedman G, Jafri S, Schultz G, Fridman A, Harding K. Gas plasma: medical uses and developments in wound care. Plasma Processes and Polymers. 2010; 7:194-211.

61. Bogle MA, Arndt KA, Dover JS. Evaluation of plasma skin regeneration technology in low-energy full-facial rejuvenation. Archives of Dermatological Research. 2007; 143:168-174.

62. Xu D, Liu D, Wang B, Chen C, Chen Z, Li D, Yang Y, Chen $\mathrm{H}$, Kong MG. In situ $\mathrm{OH}$ generation from $\mathrm{O}_{2}^{-}$and $\mathrm{H}_{2} \mathrm{O}_{2}$ plays a critical role in plasma-induced cell death. PLoS One. 2015; 10:e128205.

63. Zalcenstein A, Stambolsky P, Weisz L, Müller M, Wallach D, Goncharov TM, Krammer PH, Rotter V, Oren M. Mutant p53 gain of function: repression of CD95 (Fas/APO-1) gene expression by tumor-associated p53 mutants. Oncogene. 2003; 22:5667-5676. 